\title{
Um enfoque fora de foco: reflexões sobre o ponto de vista em "Campo geral"
}

\author{
Claudia Campos Soares \\ Universidade Federal de Ouro Preto
}

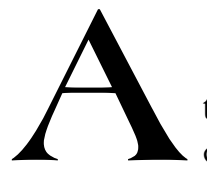

novela "Campo geral", de Guimarães Rosa, é narrada em terceira pessoa, mas seu leitor apreende a realidade ficcional da forma como ela se reflete na sensibilidade de seu personagem de maior relevo, Miguilim, um menino que tem entre sete e oito anos de idade. O narrador não impõe à estória a sua perspectiva; ao contrário, coloca-se muito próximo do personagem, por isto é capaz de expressar as nuances mais delicadas da subjetividade do menino.

A infância, como se vê, está presente na estória em dois de seus elementos constitutivos mais importantes: o protagonista e o ponto de vista. Devido a isto, Guimarães Rosa submeteu a linguagem da novela a um cuidadoso processo de nivelamento estilístico com o estágio da infância, a começar pelo vocabulário utilizado, que se aproxima de várias formas do linguajar infantil. Uma delas é a significativa e marcante presença dos hipocorísticos, os diminutivos e apelidos como o do próprio Miguilim, e o de seu irmão, o Dito, por exemplo. ${ }^{1}$

O tratamento dispensado aos parentes de Miguilim também é um procedimento estilístico que aproxima o leitor da perspectiva do menino. Eles são chamados na novela de "Pai", "Mãe", "Vovó Izidra", "Tio Terez" - justamente a forma como o menino os trataria.

Também é uma marca estilizada do linguajar infantil a freqüente exploração de efeitos lúdicos da linguagem, como nesta descrição:

${ }^{1}$ Os hipocorísticos são também marcas de linguagem afetiva. A freqüente utilização deles na narrativa contribui para a criação do efeito de simpatia que leva o leitor a se envolver na estória, a compartilhar com o protagonista as suas emoções. Esta questão será retomada no decorrer do trabalho. 
O coelhinho tinha toca na borda da mata. Saía só no escurecer, queria comer, queria brincar, sessepe, serelé, coelhinho da silva, remexendo com a boquinha de muitos jeitos, esticava pinotes e sentava a bundinha no chão, cismado (...). ${ }^{2}$

Ou em onomatopéias como esta: "O vento vuvo: viív...viív". ${ }^{3}$

Outro procedimento que contribui para criar em "Campo geral" a "sensação de infância dentro da maior verdade lírica", nas palavras de Henriqueta Lisboa ${ }^{4}$ é o uso acentuado da expressão "a gente", semanticamente ambígua, como em: "A gente - essas tristezas". 5 No caso desta frase, a expressão pode se referir a Miguilim e sua família expressão do protagonista em discurso indireto livre; mas também pode incluir o narrador - e o leitor junto com ele, como se discutirá adiante em identificação profunda com o personagem.

Às vezes estes procedimentos se conjugam e o leitor tem a impressão de estar diante de uma típica narrativa em primeira pessoa, como neste trecho: "Aqueles dias passaram muito bonitos, nem choveu: era só o sol, e o verde, veranico. Pai ficava todo o tempo nas roças (...) E era bom para a gente, quando Pai não estava em casa." ${ }^{6}$

Estas opções formais decorrem também do modo como o autor se relaciona com sua obra. Rosa identifica-se profundamente com o universo que representa literariamente. Ele é, como se sabe, original e afetivamente, um sertanejo. Suas afinidades com o mundo do sertão tornam-no capaz de "dar-se de corpo e alma às sensações do mundo e às impressões de

${ }^{2}$ Todos os trechos da novela "Campo geral" transcritos neste trabalho foram extraídos da Ficção completa (em dois volumes), editada pela Aguilar em 1994; e virão indicados pelo sobrenome do autor; seguido do número I ou II - de acordo com o volume da Ficção completa ao qual pertencer o trecho citado -; e, por fim, do número da página em que se encontra o trecho na referida edição. Este primeiro encontra-se em ROSA, I, p. 473.

${ }^{3}$ ROSA, I, p. 475.

${ }^{4}$ In: COUTINHO, 1983, p. 176.

${ }^{5}$ ROSA, I, p. 485.

${ }^{6}$ ROSA, I, p. 511. 
suas criaturas" e de configurar o mundo ficcional segundo a perspectiva delas, como observou Alfredo Bosi. ${ }^{7}$

No caso de Miguilim, Rosa se aproxima muito também biograficamente de seu protagonista. Em entrevista a Ascendido Leite, o escritor mineiro descreveu experiências de sua infância muito semelhantes às do protagonista de "Campo geral":

Não gosto de falar da infância. É um tempo de coisas boas, mas sempre com pessoas grandes incomodando a gente, intervindo, comentando, perguntando, mandando, comandando, estragando os prazeres. Recordando o tempo de criança, vejo por lá um excesso de adultos, todos eles, mesmo os mais queridos, ao modo de soldados e policiais do invasor, em pátria ocupada. Fui rancoroso e revolucionário permanente, então. Já era míope e, nem mesmo eu, ninguém sabia disto. Gostava de estudar sozinho e de brincar de geografia. Mas, tempo bom, de verdade, só começou com a conquista de algum isolamento, com a segurança de poder fechar-me num quarto e trancar a porta. Deitar no chão e imaginar histórias, poemas, romances, botando todo mundo conhecido como personagens, misturando as melhores coisas vistas e ouvidas, numa combinação mais limpa e mais plausível, porque - como muita gente compreendeu e já falou - a vida não passa de histórias mal arranjadas, de espetáculo fora de foco. ${ }^{8}$

Esta proximidade implica também em envolvimento emocional, como o próprio autor admitiu certa vez, em carta ao amigo Paulo Dantas: “(...) Aquela miopia de Miguilim foi minha. Escrevi aquela novela, em quinze dias, em lágrimas. Chorava muito enquanto a escrevia. Lágrimas sentidas, grossas, descidas do fundo do coração."

As palavras do autor têm sempre que ser consideradas com reservas. Como afirma Northrop Frye,

o autor pode naturalmente (....) falar a respeito de sua própria obra. Mas o Dante que escreve um comentário sobre o primeiro canto do Paraíso é apenas mais um dos críticos de Dante. O que ele diz tem interesse especial, mas não autoridade especial. ${ }^{10}$

\footnotetext{
7 BOSI, 1988, p. 22.

${ }^{8}$ LIMA, 1997, p. 39.

${ }^{9}$ DANTAS, 1975, p. 27.

${ }^{10}$ FRYE, 1973, p. 13.
} 
O interesse especial do depoimento de Guimarães Rosa citado anteriormente decorre do fato de ele fornecer uma possibilidade explicativa para emoções que o leitor experimenta durante a leitura da obra. "Campo geral" é uma novela que apresenta altíssima carga dramática e tem forte apelo emocional. A novela já tenderia a isto por enfocar os sofrimentos de uma criança. O envolvimento do autor no drama do personagem, entretanto, intensifica as potencialidades do tema - o que favorece, igualmente, o envolvimento do leitor e tende a provocar também a sua simpatia em relação às dores de Miguilim, como se discutirá mais detidamente adiante.

Uma das formas através das quais se expressa a proximidade de Rosa em relação ao drama do personagem é a figura do "doutor", que aparece no final da estória para salvar o menino de seu universo pobre em tantos sentidos - um doutor sentimental, que também se emociona quando Miguilim the pede os óculos para que possa ver ainda uma vez a beleza do Mutum antes de partir: "O doutor limpou a goela, disse: - 'Não sei, quando eu tiro esses óculos, tão fortes, até meus olhos enchem d'água...' ". ${ }^{11}$ Alter ego do autor em suas andanças pelo sertão ${ }^{12}$ - são ambos, criador e criatura, médicos e míopes - este "doutor" expressa o tipo de relacionamento muito íntimo que o escritor mantém com seu universo ficcional; justamente o que lhe permite, na estória de Miguilim, acompanhar os mais profundos e tortuosos caminhos da percepção do menino acerca de si mesmo e da realidade que o cerca.

Outro elemento compositivo que carrega a narrativa de alta voltagem emocional é o fato de o olhar infantil, a partir do qual nos é dado apreender o universo ficcional, ser o de Miguilim - um menino triste, confuso e amedrontado, que não entende o mundo dos adultos ao qual se vê submetido. A metáfora que representa sua visão de mundo é a da miopia, que também esta criatura compartilha com criador. A vida de Miguilim parece depender de forças obscuras, incompreensíveis; e, a despeito disto - ou justamente por isto, - cruéis e brutais: "A coisa mais difícil que tinha era a gente poder saber fazer tudo certo, para os outros

\footnotetext{
${ }^{11}$ ROSA, I, p. 542.

${ }^{12}$ Há vários "doutores" (nem sempre médicos, e/ou nem sempre identificados como tal) com esta função na obra rosiana. O mais citado é o doutor que ouve o relato de Riobaldo em Grande sertão: veredas.
} 
não ralharem, não quererem castigar". ${ }^{13}$ Miguilim sente-se permanentemente ameaçado por "coisas assustadas". ${ }^{14}$ "Tudo parecia um perigo enorme", porque as pessoas grandes lhe pareciam capazes dos maiores desatinos: "Tudo o que todo mundo fazia era errado". ${ }^{15}$

Com o pai, o menino vive sua relação de maior incompatibilidade. O choque entre os dois decorre da impossibilidade de encontro entre uma percepção e uma expressão poéticas do mundo - a de Miguilim -, e outra, extremamente prática e utilitarista - que caracteriza nhô Bernardo - um homem, além do mais, rude e violento. ${ }^{16} \mathrm{O}$ pai irrita-se freqüentemente

${ }^{13}$ ROSA, I, p. 503.

${ }^{14}$ ROSA, I, p. 480.

${ }^{15}$ ROSA, I, p. 474 e 487.

${ }^{16} \mathrm{O}$ pai de Miguilim é capataz em terra alheia e, por mais que trabalhe, não consegue sair da condição de pobreza. O esforço árduo, a natureza fatigante e opressiva de seu trabalho e o sentimento de insatisfação para com seus resultados parecem contribuir para fazer de nhô Bernardo um homem frustrado, ressentido, irascível, capaz de atitudes altamente destrutivas. Parece haver nele um potencial de ódio acumulado que ele cada vez mais alimenta, e que está sempre prestes a irromper em explosão arrasadora. É o que sugere também o seu nome. Para um escritor como Guimarães Rosa, que dá à palavra, na prosa, um tipo de tratamento que ela só costuma receber na poesia, os nomes próprios devem ser considerados com especial atenção, pois dizem muito, entre outras coisas, sobre aqueles a quem nomeiam. É o que demonstram estudos como os de SANTOS (1971) e de MACHADO (1976). No caso de nhô Bernardo, seu nome nos remete à revolta popular ocorrida em Braga, Portugal, no século XIX, a Maria Bernarda. O termo abreviado, bernarda, acabou por estender seu campo semântico, passando a significar revolta popular e desordem, em geral (FERREIRA, s/d). Oliveira Viana, uma fonte rosiana importante (cf. demonstrado em SOARES, 2002), usa o termo neste sentido (VIANNA, 1987, p. 264). O nome do pai de Miguilim sugere ainda sob outro ângulo esta sua vulnerabilidade aos impulsos para a violência, que costumam tomá-lo como a um possesso. Bernardo vem do germânico bern, variante de ber, urso; e ardo, de hart, forte (SANTOS, 1971, p. 126). O simbolismo do urso está ligado às paisagens internas da terra-mãe, ao interior ctônico e noturno. Poderoso, violento, perigoso, incontrolado, como uma força primitiva, foi tradicionalmente o emblema da crueldade, da selvageria, da brutalidade (CHEVALIER; GHEERBRANT, 1990, p. 925). 
com o temperamento sensível e delicado do filho e a relação entre eles é cheia de mal-entendidos e brutalidades. Miguilim, por seu lado, não se interessa pelo mundo do pai, que lhe parece incompreensível e violento; prefere alhear-se dele refugiando-se em sua subjetividade e/ou dedicandose a outras preocupações e prazeres mais "elevados".

Miguilim está sempre em busca de algo escondido além da aparência das coisas. É um espírito pronto à indagação, a quem respostas superficiais e convencionais não satisfazem. Ele quer saber muitas coisas e, por isto, "gostava de brincar de pensar". ${ }^{17}$ Certa vez, fingiu que precisava satisfazer necessidades fisiológicas e escondeu-se no mato para poder ficar sozinho e refletir sobre a morte, questão que o preocupava muito na ocasião. $^{18}$

Miguilim se preocupa com coisas que a maioria das pessoas de seu meio sequer tem tempo para pensar. Todos trabalham muito no Mutum. A vida é árdua, pois o meio é hostil naquela fazenda isolada nos confins dos gerais; e onde se tem que produzir quase tudo o que se necessita para viver. ${ }^{19}$ Para sobreviver ali, as pessoas têm de colocar o trabalho acima de

\footnotetext{
${ }^{17}$ ROSA, I, p. 471.
}

${ }^{18}$ ROSA, I, p. 488. Guimarães Rosa parece fazer, nesta cena, uma brincadeira com os sentidos da palavra "escatologia".

${ }^{19}$ Localizada em alguma vereda remota dos gerais, a fazenda do Mutum está rodeada de vastos e inóspitos espaços, conforme se percebe na descrição da viagem de Miguilim e Tio Terez ao arraial do Sucuriju, que abre a novela. Tio e sobrinho viajaram a cavalo durante vários dias por caminhos desérticos. O Mutum, conforme Miguilim ouviu um homem dizer no Sucuriju, "é um (...) lugar distante de qualquer parte ..." (ROSA, I, p. 465). Assim mesmo ele é apresentado já nas primeiras linhas da novela: "Um certo Miguilim morava com sua mãe, seu pai e seus irmãos longe, longe daqui, muito depois da Vereda-do-Frango-d'água e de outras veredas sem nome ou pouco conhecidas, em ponto remoto, no Mutum. No meio dos Campos Gerais, mas num covoão em trechos de matas, terra preta, pé de serra." (ROSA, I, p. 465). O Mutum é um lugar muito longínquo. Tão longínquo que muitas veredas ao seu redor não têm nome, como se se tratasse de território ainda não desbravado, aonde não chegou a ação civilizatória do homem. Marcam seu isolamento também as múltiplas barreiras que o separam do mundo exterior: situa-se num covoão - uma baixada - e é rodeado de matas e serras. O Mutum é fechado em si mesmo até no nome, um palíndromo. 
quaisquer outros interesses, como observa Miguilim: “(...) nunca que ninguém tinha tempo, quase que nenhum, de trabalhar era que todos careciam". ${ }^{20}$ Daí a valorização do proveitoso, do útil, que caracteriza a visão de mundo das pessoas dali - o pai em destaque -, concepção com a qual não compartilha Miguilim.

Nosso herói tem maiores recursos de superação da realidade imediata que seus parentes em geral - além da reflexão - como a possibilidade de fruir a beleza do mundo. Ele é capaz de absorver-se por muito tempo na contemplação da natureza, pois vê nela um espetáculo de beleza e riqueza que não podem enxergar aqueles que são totalmente absorvidos pela necessidade.

Miguilim, também como seu criador, é um inventor de mundos ficcionais; e demonstra, desde o início da estória, ter grande sensibilidade estética. Certa vez, após ouvir o filho contar estórias inventadas por ele mesmo, Nhanina diz que:

Miguilim era muito ladino, depois disse que o Dito também era. Tomezinho desesperou, porque Mãe tinha escapado de falar no nome dele; mas aí Mãe pegou Tomezinho no colo, disse que ele era um fiozinho caído do cabelo de Deus. Miguilim, que bem ouviu, raciocinou apreciando aquilo, por demais. Uma hora ele falou com o Dito - que Mãe às vezes era a pessoa mais ladina de todas. ${ }^{21}$

Miguilim reconhece a intelectualidade fina ${ }^{22}$ da mãe em sua capacidade de construir imagens poéticas. São estes mesmos os valores determinantes da admiração do menino por seu Aristeu, um vizinho da fazenda do Mutum - homem que, para Miguilim, "parecia desinventado de uma estória". ${ }^{23}$

Músico-poeta popular do sertão, seu Aristeu tem, como Miguilim, o gosto pela beleza estética. Além de recitar quadrinhas e contar estórias, ele também tocava viola e cantava. Seu Aristeu alegrava a todos quando

\footnotetext{
${ }^{20}$ ROSA, I, p. 487.

${ }^{21}$ ROSA, I, p. 512.

${ }^{22}$ Intelectualmente fino é um dos sentidos dicionarizados de ladino (FERREIRA, [s.d.].

${ }^{23}$ ROSA, I, p. 495.
} 
aparecia no Mutum, principalmente a Miguilim. Nem mesmo Vovó Izidra conseguia resistir às "coisas dançadas no ar" que dizia; até ela "tinha de se rir por ter boca". ${ }^{24}$

Miguilim também gosta muito do Grivo, o menino que "contava uma estória comprida, diferente de todas, a gente ficava logo gostando daquele menino das palavras sozinhas". ${ }^{25}$ O nome do amigo de Miguilim remete-nos ao grifo, o personagem mitológico que, na emblemática medieval, participa do simbolismo do leão e da águia, ou seja, da natureza da terra e do céu. O grifo liga o poder terrestre do leão à energia celeste da águia, inscrevendo-se, deste modo, no simbolismo geral das forças da salvação. ${ }^{26}$ Se o grifo faz a ponte com o divino, o Grivo coloca a relação entre poesia e transcendência, questão muito importante para Guimarães Rosa, como foi discutido em outra oportunidade. ${ }^{27}$

Somente a partir de uma perspectiva como a de Miguilim personagem cujo autor tem a rara capacidade de deixar falar o (seu) outro - seria possível existir um episódio como o do banho que sua mãe, aos olhos do filho, dá no corpo morto do Dito para prepará-lo para o enterro. Através da percepção delicada do menino, são dados a ver detalhes extremamente comoventes, como o cuidado vão de Nhanina em não deixar que o pé ferido do filho morto esbarrasse na borda da bacia. ${ }^{28}$ Os olhos de Miguilim permitem ver o amor da mãe pelo filho em sua inútil preocupação de poupá-lo de uma dor que ele não podia mais sentir.

Em alguns momentos de maior impacto emocional, o narrador aproxima-se tanto do personagem que tende a apagar-se a categoria do narrador. Sendo este último um intermediário entre autor e o leitor, este apagamento é um dos principais elementos que levam ao envolvimento também do destinatário da mensagem na realidade ficcional, de que se falou anteriormente. "Campo geral" - como, em graus diversos, as demais novelas de Corpo de baile - desenvolve(m)-se "num teatro em que não

\footnotetext{
${ }^{24}$ ROSA, I, p. 496.

${ }^{25}$ ROSA, I, p. 510.

${ }^{26}$ CHEVALIER; GHEERBRANT, 1990, p. 478.

${ }^{27}$ SOARES, 2002.

${ }^{28}$ ROSA, I, p. 522.
} 
há separação entre palco e platéia" ${ }^{29}$ A proximidade entre autor e personagem transporta também o leitor para dentro da ficção envolvendoo nos sentimentos de Miguilim e levando-o a comover-se com as experiências do menino e dos seus.

Tal envolvimento parece comprometer a objetivação e a distância próprios do pensamento crítico. Pasta Jr. observou a questão do prisma de Grande sertão: veredas, mas, em maior ou menor escala, a observação é válida para toda a obra rosiana:

(...) Tudo se passa como se, por sua constituição mesma e pelo pacto que firma com seu leitor, esse livro transcendesse a categoria estéticoliterária do enigma, que no entanto é a sua, para tender àquela, mágicoreligiosa, do mistério. Como se sabe, enigmas pedem decifração, mistérios admitem unicamente culto e celebração. O Grande sertão: veredas parece pedir ambas as coisas e, de modo menos ou mais sutil, não é raro ver-se, diante dele, o ofício do crítico desdobrar-se na celebração do oficiante - os elementos de objetivação e de distância, próprios do discurso crítico, desdobrando-se em um rito de comunhão com a obra, no qual os limites entre sujeito e objeto, o mesmo e o outro, tornam-se ao mesmo tempo fluidos e indecidíveis. (...) quem quiser de fato ler o Grande sertão guardando fidelidade à demanda do livro, terá que lê-lo ao mesmo tempo com o isolamento e a distância que supõe o romance moderno e com o fusionamento e a participação que, no limite, só conhecem o mito e o rito. ${ }^{30}$

O leitor de Guimarães Rosa é sempre desafiado a se equilibrar num limite tênue, pois um certo nível de adesão também é demanda da obra. A concepção rosiana de literatura aproxima-se de perspectivas muito antigas, ligadas ao mito - como por exemplo, as que se revelam nos poemas de Hesíodo e de Homero. E também da visão platônica segundo a qual a poesia é vista como divinamente inspirada, resultante de um

\footnotetext{
${ }^{29}$ RÓNAI, 1958, p. 140. Como se sabe, "Campo geral" é parte integrante de um conjunto de sete novelas intitulado Corpo de baile. Devido à divisão do livro em três volumes a partir da $3^{a}$ edição, a novela hoje se publica em volume intitulado Manuelzão e Miguilim, junto a "Uma estória de amor" (ROSA, 2001).

${ }^{30}$ PASTA Jr., 1977, p. 159-160.
} 
estado de possessão. No Íon, por exemplo, Sócrates ainda se refere ao poeta como um iluminado pelos deuses ${ }^{31}$; e, no Fedro, ele considera este estado de possessão divina superior, inclusive, à sobriedade racional, tão exaltada pelo mestre de Platão como instrumento de acesso à verdade. ${ }^{32}$

Estas concepções são afins à visão de mundo apresentada pela obra de Guimarães Rosa porque, estando na origem da cultura ocidental, refletem um momento em que razão, emoção, intuição, religião ainda não eram concebidos como domínios completamente isolados. Nestes "princípios dos tempos", estas diversas dimensões do humano ainda estavam, em graus diversos, aliadas na busca do homem de compreensão de si mesmo e do mundo.

Do mesmo modo, no universo rosiano o homem não é reduzido a sua dimensão racional e a realidade tem dimensões misteriosas. Aí também parece não haver muita separação entre a arte e a esfera do divino. Subjaz a esta obra a concepção de que a poesia nasce de tomadas de consciência muito intensas, de "revelações".

Em diversas ocasiões, Rosa afirmou escrever possuído. A Paulo Dantas disse a respeito da gênese de Grande sertão: veredas:

Os caboclos "baixaram" em mim... Só escrevo altamente inspirado, como que tomado, em transe. Aquele livro me cansou fisicamente. Acabei extenuado. Deu-me, porém, um enorme prazer. Sensação igual só senti ao escrever "Miguilim". Foi outro clarão que recebi na vida..$^{33}$

Tal concepção ainda encontra ressonância no referente sóciocultural que o escritor adota para sua obra. Esta mistura razão-emoçãoreligião também está presente na cultura popular do sertão, onde o insulamento cultural favorece a permanência de concepções míticas de mundo.

A obra que permite o encontro entre o "sertão" e o "mundo" é estruturada "em camadas". Seus personagens são sertanejos, sua linguagem é uma estilização do falar sertanejo, o cenário das narrativas também é predominantemente o sertão (e/ou seus arredores). Desta

\footnotetext{
${ }^{31}$ PLATÓN, 1990, p. 143-152.

32 PLATÓN, 1990, p. 847-884.

${ }_{33}$ DANTAS, 1975, p. 28.
} 
matriz histórico-geográfico-social, entretanto, se pode transitar a "regiões da alma", nas palavras de Antonio Candido ${ }^{34}$. Isto porque numa primeira camada de significação as narrativas figuram o sertão geográfico e histórico-social ${ }^{35}$; ligada a esta, entretanto, há uma outra camada, mais profunda, na qual se encontram os sentidos metafísico-religiosos das estórias - que Guimarães Rosa hauriu, principalmente, de sua experiência no plano da chamada "alta cultura".

Guimarães Rosa, sertanejo e diplomata, consegue vislumbrar uma área de correspondência entre realidades culturais muito distintas, pois tem a sensibilidade habituada tanto ao mundo da cultura erudita quanto ao da cultura popular do sertão. Seu contato com as fontes míticas e místicas (e outras) da literatura universal permite que ele estabeleça pontos de conexão entre os dois universos, a partir dos quais pode disseminar pelo texto elementos que sugiram outros níveis de significação. A propósito, vale lembrar que a possessão de que fala Rosa é a dos "caboclos".

Vale a pena lembrar também a forma como Guimarães rosa optou por apresentar o livro. Na primeira edição de Corpo de baile, ele o fez por meio de oito epígrafes: quatro trechos das Enéadas, de Plotino; três de O anel ou a pedra brilhante, de "Ruysbrock, o Admirável", místico brabanção do século XIV; e a letra de um coco, o "coco de festa do Chico Bráboz" - que, segundo o próprio Rosa, em carta ao tradutor italiano, teria sido literalmente transcrito da cultura popular da região natal do autor. ${ }^{36}$

Interessa aqui ainda ressaltar uma aproximação de Rosa a Aristóteles através da concepção de catarse - o envolvimento do espectador no drama representado, a mistura que ele experimenta de compaixão, temor quanto ao destino do herói e a purgação destas emoções. Como afirmou René Girard,

(...) Ao descrever o efeito trágico em termos de katharsis, ele (Aristóteles) afirma que a tragédia pode e deve preencher ao menos

${ }^{34}$ In: COUTINHO, 1983, p. 295.

${ }^{35} \mathrm{E} / \mathrm{ou}$ uma representação de interpretações dele. Guimarães Rosa constrói seu universo ficcional baseando-se também em estudos sobre a realidade brasileira como os de Gilberto Freyre e Oliveira Vianna, como também já foi discutido em outra ocasião. (SOARES, 2002).

${ }^{36}$ BIZZARI, 1981, p. 24. 
algumas das funções reservadas ao ritual em um universo onde este desapareceu. ${ }^{37}$

É algo parecido o que acontece no universo rosiano, onde se revela uma concepção estética que vê na literatura fins mais altos que os exclusivamente literários. A obra rosiana põe em questão o problema da relação entre realidade sensível e o domínio do supra-sensível, entre as coisas cognoscíveis e incognoscíveis, entre a natureza, a sociedade, o homem e o mistério. E mais do que isto: a literatura, em Guimarães Rosa, deve servir a fins éticos, morais e até mesmo religiosos. Como observou Benedito Nunes, as narrativas rosianas são instrumentos de depuração do homem e desempenham função anagógica.

Isto justificaria também sua "poesia", como observou o mesmo crítico. A aproximação à perspectiva da criança em "Campo geral" permitiu também a Guimarães Rosa a exploração de aspectos lúdicos da linguagem - como as onomatopéias, a utilização de palavras raras, estranhas, ressonantes, sem significado aparente, como se viu, por exemplo, em relação à descrição do coelhinho, anteriormente mencionada. Tratam-se estes de procedimentos próprios à poesia. Bem como os que Franklin Oliveira chamou de "explosão de imagens condensadas"; ${ }^{38}$ Benedito Nunes, de "soltura dos vocábulos encadeados em ritmo"; 39 e Roberto Schwarz, de "libertação do vocábulo que identificamos com lirismo" todos referindo-se às narrativas de Guimarães Rosa.

Partindo da tipologia do romance formulada por Lucien Goldman, Bosi atribui a elas a classificação de "romances de tensão transfigurada", que assim define: "O herói procura ultrapassar o conflito que o constitui existencialmente pela transmutação mítica ou metafísica da realidade. (...) O conflito assim 'resolvido', força os limites do gênero romance (...)". ${ }^{41}$ Mais adiante, Bosi continua: "a invenção mitopoética (...) tende a romper com a entidade tipológica 'romance', superando-a no tecido da linguagem

\footnotetext{
${ }^{37}$ GIRARD, 1998, p. 364.

38 Apud NUNES, 1998, p. 250.

39 NUNES, 1998, p. 250.

${ }^{40}$ SCHWARZ, 1965, p. 26.

${ }^{41}$ BOSI, 1983, p. 442.
} 
e da escritura, isto é, no nível da própria matéria da criação literária" ${ }_{4}^{42}$ No caso de Guimarães Rosa, o procedimento coloca alguns trechos do livro (deste e de outros seus) em um terreno muitas vezes indistinguível entre a poesia e a prosa.

A linguagem poeticamente trabalhada remete-nos de volta ao aspecto transcendente da literatura em Guimarães Rosa. Benedito Nunes coloca o problema nos seguintes termos:

(...) a beleza contemplada nas coisas, somada ao efeito do "canto e da plumagem das palavras" que a possibilita, seria o meio, à disposição do ficcionista, para religar-se e religar o leitor à realidade superior (religião vem de religare). (...) no conjunto da obra (...) há tanto de poético quanto de religioso, e é difícil separá-los do mito, a que se encontram muitas vezes interligados. ${ }^{43}$

Como observou ainda o crítico, estes procedimentos também relacionam Corpo de Baile e o neoplatonismo, que aparece como fonte rosiana explícita nas epígrafes do livro. Por buscarem a salvação do homem, tanto o discurso neoplatônico quanto as narrativas rosianas articulam forte elã religioso e discurso poético. ${ }^{44}$

A ficção como meio de depuração religiosa do homem, graças ao efeito anagógico sobre o leitor da narrativa poeticamente trabalhada, cuja linguagem, de ressonância contemplativa e de amplitude alegórica, eleva-o a um plano superior, metafísico, está em harmonia com as marcas distintivas do pensamento neoplatônico, que sobressaem dos principais textos de Rosa. ${ }^{45}$

É bom, entretanto, não perder de vista nenhum dos lados da questão. Ler Guimarães Rosa requer uma mistura equilibrada de adesão e distanciamento. Trata-se este daquele que foi considerado por Paulo Rónai "o mais consciente de nossos escritores". Na mesma ocasião, o crítico se refere à "verdadeira corrida de obstáculos" a que Rosa submetia

\footnotetext{
${ }^{42}$ BOSI, 1983, p. 444.

43 NUNES, 1998, p. 253.

${ }^{44}$ NUNES, 1998, p. 259.

${ }^{45}$ NUNES, 1998, p. 258.
} 
os críticos ${ }^{46}$, revelando o alto grau de consciência com que o escritor se utilizou de procedimentos e elementos na construção de sua obra "em camadas". Revelam explicitamente o seu alto grau de consciência criativa, por exemplo, a correspondência que costumava manter com seus tradutores ${ }^{47}$ e os prefácios de Tutaméia, onde apresenta, um pouco menos diretamente, algumas de suas concepções estéticas.

O ponto de vista de "Campo geral" também é uma construção onde isto pode ser observado. Aí se conjuga uma certa visão ingênua, imperfeita e parcial (a de Miguilim) e a possibilidade de ver um pouco além dela.

Como foi dito, o universo ficcional nos é apresentado pelos olhos de um menino que não compreende o mundo dos adultos, não é considerado nem se interessa por ele; e é míope. Por um lado este ponto de vista permite o poético, como foi visto. Por outro, entretanto, ele é restritivo em relação ao acesso às informações narrativas. Não enxergando o que acontece, Miguilim não pode dar a vê-lo. Por ser este menino quem orienta a perspectiva, muitos dados que nos chegam da realidade que o rodeia são obscuros e imprecisos. A estória nos assegura pouca coisa inequivocamente acerca dos acontecimentos que ocorrem no Mutum. "Campo geral" é uma estória de conflitos alimentados por motivações obscuras, hostilidades latentes, prestes a irromper a qualquer momento - e irrompem, acarretando gravíssimas conseqüências para todo o grupo familiar -, mas só nos é dado imaginar as conformações gerais destes conflitos, não podemos precisar seus contornos exatos.

O autor, no entanto, não está inteiramente absorvido pelo protagonista. Ele também está por trás do discurso ficcional criando condições de reconhecimento do ambiente e dos conflitos que rodeiam Miguilim para além da capacidade de percepção do menino. Por isto, tomamos conhecimento de alguns dos fatos, circunstâncias e/ou situações da estória apenas de forma indireta ou quase acidental. Por esta particularidade da narrativa, o leitor fica situado, simultaneamente, junto e além da perspectiva do protagonista, o que faz com que saibamos algumas coisas junto com Miguilim e outras até além dele.

Na passagem transcrita abaixo, por exemplo, é nhô Bernardo quem, em sua frustração colérica, evidencia a situação econômico-social da família:

\footnotetext{
${ }^{46}$ RÓNAI, 1978, p. IX.

${ }^{47}$ V., por exemplo, BIZZARI, 1983 e ROSA, 2003.
} 
(...) Como o pai ficava furioso: até quase chorava de raiva! Exclamava que ele era pobre, em ponto de virar miserável, pedidor de esmola, a casa não era dele, as terras ali não eram dele, o trabalho era demais, e só tinha prejuízo sempre, acabava não podendo nem tirar para o sustento de comida da família. Não tinha posse nem pra retelhar a casa velha, estragada por mão desses todos ventos e chuvas, nem recursos para mandar fazer uma boa cerca de réguas, era só cerca de achas e paus pontudos, perigosa para a criação. Que não podia... Dava vergonha no coração da gente, o que o pai assim falava. ${ }^{48}$

Nhanina também dá explicações econômico-sociais para o comportamento violento do marido. Em uma ocasião em que tenta consolar Miguilim da brutalidade paterna, diz ao filho que nhô Bernardo agia desta forma porque trabalhava demais para tirar a família da pobreza. ${ }^{49}$

Mas é principalmente através do Dito, o irmãozinho esperto de Miguilim, que o leitor toma conhecimento da - ou percebe indícios que o levam a levantar hipóteses sobre a - maioria dos problemas da família. É o Dito quem informa ao irmão - e ao leitor, indiretamente -, por exemplo, que nhô Bernardo é somente arrendatário, não proprietário, da fazenda onde moram. ${ }^{50}$ Por sua proximidade com Miguilim e sua perspicácia, Dito é um dos personagens que mais freqüentemente nos apresentam os acontecimentos que o "olhar imperfeito" do irmão, sozinho, não poderia dar a ver.

A visão que prevalece, entretanto, é a que nos permite este olhar imperfeito. E ela é insuficiente, por exemplo, para esclarecer muitas das motivações e comportamentos dos adultos do Mutum. É o que se verifica, por exemplo, em relação à mãe de Miguilim.

Nhanina é carinhosa, delicada e gentil com os filhos, que gostam muito dela. ${ }^{51}$ Ela revela, sob vários ângulos, mais civilidade que o marido

\footnotetext{
${ }^{48}$ ROSA, I, p. 490.

${ }^{49}$ ROSA, I, p. 532.

${ }^{50}$ ROSA, I, p. 501.

${ }^{51}$ Conforme também o expressa seu nome. Nas palavras de Júlia F. Santos, "efeitos de reverberação timbrística tem-se com Nhanina (...) pela utilização, em tom afetivo, de composições com o fonema /n/. (...) tanto Guimarães Rosa quanto Miguilim se comprazem com as composições baseadas na nasal
} 
rústico e rude. Sabe ler, ao contrário dele, ${ }^{52}$ e a isto parece corresponder uma complexidade maior de seu universo simbólico. A vida para ela tem dimensões além da imediata, prática, a única que é capaz de conceber seu marido, cujas percepções estão inteiramente ligadas ao útil e ao proveitoso. Como Miguilim, ela é sensível à beleza estética: gosta muito de ouvir a viola de seu Aristeu e valoriza no filho sua habilidade de contar estórias, bem como demonstra ser também capaz de utilizar recursos da imaginação para construir imagens poéticas, como já foi citado aqui.

No entanto, é uma mulher triste. Nhanina "se doía de tristeza de ter de viver ali". ${ }^{33}$ Seu único desejo explícita e recorrentemente expresso ao longo da novela é se mudar do Mutum. Talvez para a cidade, onde parece já ter morado. Nhanina sabe o que é o teatro e o circo, pois o explica a Miguilim certa vez; ${ }^{54}$ e não pode tê-los conhecido naquelas paragens tão longínquas. Além disto, como sabe ler, talvez já tenha até mesmo freqüentado uma escola.

Nhanina parece sentir-se limitada pela vida que leva no Mutum. Sua tristeza (pelo menos parte dela) decorre de um sentimento de insatisfação pelo que está deixando de viver, encerrada num mundo sem horizontes. Olhando o morro que separa a fazenda do mundo exterior, ela diz ao filho certa vez: "Estou sempre pensando que lá por detrás dele acontecem outras coisas, que o morro está tapando de mim, e que eu nunca hei de poder ver..." 55

Sejam lá quais forem estas coisas. Como foi dito anteriormente, ao leitor de "Campo geral" não é dado saber com certeza muito mais do que o que foi afirmado acima. Não se conhece a história desta mulher, seus

palatal. Um exemplo disto é o fato de ter Miguilim batizado um passarinho que ele achava muito bonito (um nhambu) de Nhá Nhambuzinha, e o fato de se notar da parte de GR uma certa ternura pelos personagens que batiza com formas semelhantes (cf. Nhinhinha, Nhorinhá...)." (SANTOS, 1971, p. 122).

52 ROSA, I, p. 483.

53 ROSA, I, p. 421.

${ }^{54}$ ROSA, I, p. 477.

${ }_{55}$ Miguilim observa que sua mãe diz isto "agravada de calundu e espalhando suspiros, lastimosa" (ROSA, I, p. 466). 
desejos, seus sonhos, nem as pressões às quais pode estar submetida. Na verdade, imagina-se algumas destas coisas, mas a visão "fora de foco" de Miguilim, muitas vezes acrescida de outros limites, não nos permite muito mais do que formular hipóteses.

O leitor de "Campo geral" não é esclarecido também sobre muitos acontecimentos objetivos - mesmo sobre alguns de extrema gravidade que determinam a vida dos moradores do Mutum. Não nos é dado compreender com segurança as motivações de muitos dos seus comportamentos, mesmo os mais determinantes para o destino da família. O exemplo mais notório é o assassinato de Luisaltino seguido do suicídio do pai de Miguilim. Tais acontecimentos se dão quando o menino estava doente, fora de seu estado normal de consciência. ${ }^{56}$

A estória, entretanto, fornece pistas de possibilidades explicativas também para este fato - que o relacionam, justamente, à mãe de Miguilim. O leitor de "Campo geral" é levado a fazer certas suposições devido à presença de sugestões mais ou menos explícitas, dispostas ao longo da novela. Muitas indicações nos levam a considerar a possibilidade de que, condenada a uma existência limitada, Nhanina transforme sua insatisfação em carência afetiva e/ou sexual e, em decorrência disto, envolva-se em relacionamentos extraconjugais compensatórios.

O primeiro destes relacionamentos seria com Tio Terez, o irmão de seu marido. Indica-o a briga de nhô Bernardo com a mulher logo no início da estória, seguida da expulsão de casa de Tio Terez por Vovó Izidra. Na ocasião, Miguilim escutou-a ainda repreender asperamente o provável amante de Nhanina nestes termos: "por umas coisas assim é que há questões de briga e de morte, desmanchando as famílias". ${ }^{57}$

No desenrolar dos acontecimentos subseqüentes, Vovó Izidra também repreende, obliqüa e duramente, a mãe de Miguilim:

(...) E ela ensinava alto que o demônio estava despassando nossa casa, rodeando, os homens já sabiam o sangue um do outro, a gente carecia de rezar sem esbarrar. Mãe ponteava, com muita cordura, que Vovó izidra devia de não exaltar coisas assim, perto dos meninos. - "Os meninos necessitam de saber, valença de rezar junto. Inocência deles

\footnotetext{
${ }^{56}$ ROSA, I, p. 538.

${ }^{57}$ ROSA, I, p. 473.
} 
é que pode livrar a gente de brabos castigos, o pecado já firmou aqui no meio, braseado, você mesma é quem sabe, minha filha!..." 58

Imediamente depois destas palavras, como se por um processo inconsciente de associação de idéias, Miguilim se lembra de Vó Benvinda - e assim o leitor passa a saber da existência desta avó, mãe de sua mãe, que fora prostituta. Só então tomamos conhecimento também de que aquela que é chamada de avó - Vovó Izidra - é, na verdade, tia-avó das crianças e tia de Nhanina.

A referência de Vovó Izidra ao "pecado" que já estaria instalado no seio da família - como sua sobrinha melhor do que ninguém o saberia , seguida da referência à avó prostituta, sugere também a possibilidade da associação entre mãe e filha no que se refere ao comportamento em relação aos homens. Ou seja, sugere que Nhanina tenha herdado da mãe as inclinações responsáveis pelo seu "mau comportamento" conjugal. A censura à sobrinha prossegue nos seguintes termos: "O que vovó Izidra estava falando - ... 'Só por sua casa porta afora'... - A nossa casa? E que o demônio diligenciava de entrar em mulher, virava cadela de satanaz..."

Um outro elemento que conta a favor da possibilidade de haver um envolvimento mais íntimo entre os cunhados é a fala do Dito, na mesma ocasião - uma noite em que se armava uma grande tempestade. O irmãozinho sábio de Miguilim a interpreta desta forma: "Por causa de Mamãe, Papai e tio Terez, Papai-do-Céu está com raiva de nós de surpresa..."60

Além disto, certos sinais, ainda que vagos, parecem apontar na direção da possibilidade de o sugerido envolvimento de Nhanina e Tio Terez ser antigo. Por isto - e por algumas outras indicações, mais ou menos imprecisas, que, na medida em que vão se somando umas às outras, ajudam a compor uma hipótese cada vez mais plausível -, o leitor de "Campo geral" é levado a ter dúvidas acerca da paternidade de Miguilim.

Dentre estas indicações, está o fato de não haver semelhanças de nenhum tipo entre ele e nhô Bernardo. O autor fez questão de assinalar

\footnotetext{
${ }^{58}$ ROSA, I, p. 477-478.

${ }^{59}$ ROSA, I, p. 478.

${ }^{60}$ ROSA, I, p. 475.
} 
grande diferença física entre os dois: Miguilim tem os cabelos pretos da mãe - ao contrário do pai, que é ruivo. ${ }^{61}$ Das diferenças de temperamento entre os dois já se falou aqui.

Importa ainda observar que, se Miguilim não tem afinidades com o pai, tem muitas com Tio Terez. A relação com aquele a quem chama de tio é respeitosa, harmônica, amorosa. Miguilim se refere sempre afetuosamente ao irmão de nhô Bernardo; que, por sua vez, também é carinhoso e atencioso com o menino. Com Miguilim, Tio Terez é "de brincadeiras e caçoadas" ${ }^{2}$; e muitas vezes tenta compensá-lo dos sofrimentos impingidos pelo pai oficial - como no episódio em que ensina o menino a armar arapucas para caçar passarinhos numa ocasião em que nhô Bernardo, para castigar Miguilim, levara todos os seus irmãos para pescar menos ele. ${ }^{63}$

Tio Terez parece significar para o menino o lado positivo da figura paterna. Ao contrário dele, o pai oficial é tão brutal com Miguilim que às vezes lhe dá a impressão de odiá-lo (como se, talvez - por estes e/ou outros motivos -, também desconfiasse de que não fosse seu pai?). Depois da morte do Dito, nhô Bernardo chega a dizer ao menino que preferia que tivesse sido ele a morrer, ao invés de seu irmão mais novo. ${ }^{64}$ Nhô Bernardo costumava tratá-lo tão mal que Miguilim se surpreende enormemente quando percebe, quase no final da novela, que o pai tinha amor por ele. Trata-se do episódio da doença do menino, em que, ainda que "com uma brabeza toda", o pai demonstrava grande dor com a possibilidade de perder também Miguilim. ${ }^{65}$

As sugestões do adultério de Nhanina - somadas a outras apontadas aqui que também contribuem no sentido de indicar uma propensão sua a se envolver em relacionamentos extra-conjugais ${ }^{66}$ - levantam a

\footnotetext{
${ }^{61}$ ROSA, I, p. 468.

${ }^{62}$ ROSA, I, p. 465.

${ }^{63}$ ROSA, I, p. 466.

${ }^{64}$ ROSA, I, p. 526.

${ }^{65}$ ROSA, I, p. 537.

${ }^{66}$ Propensão esta que talvez tenha entre suas motivações um sentimento de insatisfação com as circunstâncias em que a personagem vê circunscrita sua vida, como foi dito.
} 
possibilidade de que aquela família se construa apoiada em bases muito problemáticas. Uma relação entre ela e Tio Terez que pudesse ter resultado em filhos abalaria profundamente a estrutura familiar, porque embaralharia completamente as relações nas quais ela se sustenta. Só se pode falar em família se são respeitadas, no grupo, certas condições básicas, como a sucessão regrada das gerações e as distinções entre os seus membros. As relações de parentesco que a definem só existem graças a certas interdições, como as do adultério e do incesto.

Este embaralhamento nas relações pode ser verificado nas próprias noções de ordenação simbólica, pois relacionamentos desregrados acabam por desarticular também os modos de representação. As formas de tratamento de alguns personagens de "Campo geral" expressam justamente a possibilidade da confusão nas relações de parentesco desta família. A que é chamada Vovó Izidra por Miguilim, por exemplo, não é sua avó, mas tia-avó. E Tio Terez pode ser seu pai. Se assim o for, o que é chamado de pai é que seria o tio do menino; e vice-versa.

Há sugestões também de que Nhanina substitua bastante rapidamente os objetos de seu desejo. Depois da calma que se seguiu à partida de Tio Terez do Mutum, insinua-se um certo interesse especial da parte da mãe de Miguilim em relação a seu Aristeu, o vizinho que, além de violeiro, era também, em suas palavras, "um homem bonito e alto". Estas palavras são seguidas de reticências, pontuação que transmite a elas uma inflexão que permite ao leitor pensar que Nhanina poderia até ter suspirado depois de proferi-las.

Parece confirmar este interesse "reprovável" de Nhanina pelo vizinho do Mutum o comportamento de Vovó Izidra que se segue ao comentário da sobrinha: "Vovó Izidra reprovava: 'Mas do demo que a ele ensina, o curvo, de formar profecia das coisas...' ". ${ }^{67}$ A indisposição desta incansável vigilante da ordem familiar para com seu Aristeu talvez possa significar exatamente que ela, conhecendo a sobrinha que tinha, percebia em seu Aristeu um perigo aos interesses familiares que acreditava representar.

Um pouco mais tarde, Luisaltino, o novo trabalhador contratado para substituir Tio Terez nas lides da fazenda, parece substituí-lo também no coração da mãe de Miguilim. Há algumas indicações neste sentido,

${ }^{67}$ ROSA, I, p. 484. 
como a conversa à parte entre os dois em uma certa noite de lua muito especial, em que, excepcionalmente, nhô Bernardo e Vovó Izidra estão ausentes de casa:

(...) Lua era o lugar mais distanciado que havia, claro impossível de tudo. Mãe conversando só com Luisaltino, atenção naquilo ela nem não estava pondo. Uma hora, o que o Luisaltino falou: que judiação do mal era por causa de que os pais casavam as filhas muito meninas, nem deixavam que elas escolhessem noivo. Mas Miguilim queria que, a lua assim, Mãe conversasse com ele também, com o Dito, com Drelina, a Chica, Tomezinho. A gente olhava Mãe, imaginava saudade. ${ }^{68}$

Nhanina se isola dos demais, a Miguilim parece que absorta na conversa com Luisaltino - que talvez identifique nela a carência e a insatisfação que poderia tornar possível um relacionamento mais íntimo entre eles. Numa conversa que tem ares de "cantada" a uma mulher carente, as palavras do novo morador do Mutum sugerem que Nhanina tenha sido vítima de um casamento arranjado por seus pais. Ela estaria, portanto, presa a uma vida que não escolheu, o que justificaria sua insatisfação e até mesmo, eventualmente, que traísse o marido. ${ }^{69}$

Miguilim parece sentir ciúmes da atenção toda especial que sua mãe dedicava ao novo trabalhador da fazenda; e/ou talvez tivesse presságios. Sintonizado no regime noturno do espírito que a lua simboliza ${ }^{70}$, talvez intuísse as tristes conseqüências do encontro a que presenciava: "A gente olhava mãe, imaginava saudade."

${ }^{68}$ ROSA, I, p. 513.

69 As conversas entre Nhanina e Luisaltino são muito íntimas. Eles falam também de Tio Terez, por exemplo, em outra ocasião (ROSA, I, p. 511). Tocar a sensibilidade da mãe de Miguilim demonstrando proximidade e compreensão pode ser o artifício utilizado por Luisaltino para seduzi-la uma mulher sobre quem há muitas indicações de ser insatisfeita com a vida que leva, de que se sinta aprisionada e sem perspectivas; e, portanto, de que seja carente, impressionável, vulnerável.

${ }^{70}$ A lua, por sua forma cambiante, representa, entre outras coisas, o que foge à cristalização conceitual. É lunar, por exemplo, o mundo das intuições e dos presságios. 
Apesar disto, entretanto, não pode fazer nada a respeito. Neste momento, muitas questões parecem se colocar para Miguilim, como o da relação - ou da ausência dela - entre o amor e a possibilidade de se proteger a quem se ama. E/ou a da impossibilidade de se conservar, pelo amor, a pessoa amada junto de si. E/ou a da impossibilidade, sequer, de conhecê-la em sua complexidade humana. Para Miguilim começa a se delinear a consciência trágica do "mundo sem remédio", da "vida sem conserto"; e também a da irredutível alteridade do objeto do amor humano, expressos nesta forma paradoxal: "o claro impossível de tudo". ${ }^{71}$

Reforça ainda a possibilidade da relação Nhanina-Luisaltino o assassinato do suposto rival pelo pai de Miguilim, no final da estória. E o sentimento de culpa da mãe, que ela afirma ao negar. Na manhã seguinte ao terrível acontecimento, Nhanina tem esta reação diante de Miguilim: "Mãe veio, se ajoelhou, chorava tapando a cara com as duas mãos: - 'Miguilim, não foi culpa de ninguém, não foi culpa...' - todas as vezes ela repetia."72

Finalmente, sugerem também o envolvimento entre Nhanina e Luisaltino as perguntas do astuto Dito a Miguilim - quando doente e impossibilitado de sair da cama para ir verificar por si mesmo - sobre se Vovó Izidra andava repreendendo a mãe deles, quando não havia ninguém por perto. $^{73}$

Embora quase tudo o que aqui foi dito sejam conjecturas, são conjecturas que a estória nos leva, insistentemente, a fazer. "Campo geral" oferece reiterados elementos para que levantemos estas possibilidades; elas são, portanto, também parte da obra.

${ }^{71}$ A pergunta de Miguilim pelo sentido da existência no final da estória ratifica esta concepção: "Mãe, mas por que é, então, para que é, que acontece tudo?!" Diante da comovente demanda de sentido do filho, impossível de ser preenchida, a mãe só pode dizer: "Miguilim, me abraça, meu filhinho, que eu te tenho tanto amor..." José Miguel Wisnik observou que "... nos significantes 'Mãe, mas..., então...?' (...) estão assinalados o apelo, o desamparo, a cobrança da promessa de uma continuidade do sentido, já perdida, a despedida acusando o golpe de um mundo que finda, e um puro nãoverbalizável que se pode chamar de amor (a mãe chamará explicitamente amor, sabendo que um não-verbalizável - 'me abraça, meu filhinho' - tenta cobrir a enorme falta)" (WISNIK, 1996, p. 209-210).

${ }^{72}$ ROSA, I, p. 538.

${ }^{73}$ ROSA, I, p. 520. 
Mas somente enquanto possibilidades. Nesta novela, como no mundo rosiano em geral, predomina a atmosfera nebulosa, a ausência de certezas. Em "Campo geral" isto se expressa, entre outras coisas, no olhar imperfeito que constitui o ponto de vista da novela, metáfora da busca trágica de pontos de apoio e referência, de sinais de inteligência no vasto domínio do confuso e do misterioso que é a vida humana. Acerca de si, do outro e da aventura dos homens no mundo, o saber possível é nebuloso, de natureza ambígua, nunca pode ser alcançado totalmente. Rosa reproduz a opacidade do mundo na visão imprecisa, no "espetáculo fora de foco" que nos apresenta através dos olhos de Miguilim.

\section{Referências Bibliográficas}

BIZZARRI, Edoardo. João Guimarães Rosa: correspondência (com seu tradutor italiano). $2^{\mathrm{a}}$ ed. São Paulo: T. A. Queiróz, Instituto Cultural Ítalo-Brasileiro, 1980. $147 \mathrm{p}$.

BOSI, Alfredo. Céu, inferno. In: . Céu, inferno: ensaios de crítica literária e ideológica. São Paulo: Ática, 1988. p. 10-32.

BOSI, Alfredo. História concisa da literatura brasileira. $3^{\text {a }}$ ed. São Paulo: Cultrix, 1983. $584 \mathrm{p}$.

CHEVAliER, J; GHEERBRANT, A. Dicionário de símbolos. Tradução de Vera da Costa e Silva et al. $3^{\text {a }}$ ed. Rio de Janeiro: José Olympio, 1990. 996 p.

COUTINHO, Eduardo (org.). Guimarães Rosa. Rio de Janeiro: Civilização Brasileira; Brasília: INL, 1983. 581 p. [Coleção Fortuna Crítica]

DANTAS, Paulo. Sagarana emotiva. São Paulo: Duas cidades, 1975. 123 p.

FERREIRA, Aurélio B. de H. Novo dicionário da lingua portuguesa. Rio de Janeiro: Nova Fronteira, [s/d]. 1500 p.

FRYE, Northrop. Anatomia da crítica. Tradução de Péricles Eugênio da Silva Ramos. São Paulo: Cultrix, 1973. 362 p.

GIRARD, Genet. A violência e o sagrado. Tradução de Martha Conceição Gambini. Rio de Janeiro: Paz e Terra, 1998. 410 p.

LIMA, Sônia Maria van Dick Lima (Org.) Ascendino Leite entrevista Guimarães Rosa. João Pessoa: Editora Universitária/UFPB, 1997. 85 p.

MACHADO, Ana Maria. Recado do nome. Rio de Janeiro: Imago, 1976. 146 p. 
NUNES, Benedito. De Sagarana a Grande sertão: veredas. In: Crivo de papel. São Paulo: Ática; Rio de Janeiro: Fundação Biblioteca Nacional; Mogi das Cruzes: Universidade de Mogi das Cruzes, 1998. p. 247-262.

NUNES, Benedito. A matéria vertente. In: Seminário de ficção mineira II: de Guimarães rosa aos nossos dias. Belo Horizonte: Conselho Nacional de Cultura, 1983. p. 9-29.

PASTA Jr., José Antônio. O romance de Rosa: temas do Grande sertão e do Brasil. La ville - exaltation et distanciacion: études de littérature portugaise et brésilienne. Paris, n. 4. p. 159-170, [s/m] 1977,.

PLATÓN. Obras completas. $2^{a}$ ed. Tradução de Francisco de P. Samaranch. Madri: Aguilar, 1990, 1715 p.

RÓNAI, Paulo. Encontros com o Brasil. Rio de Janeiro: MEC/INL, 1958. p.129-158.

RÓNAI, Paulo. Os vastos espaços. In: ROSA, Guimarães. Primeiras estórias. $11^{a}$ ed. Rio de Janeiro: José Olímpio, 1978. p. VII - XXXII.

RONCARI, Luiz Dagobert de Aguirra. Irmão Lélio, Irmã Lina: incesto e milagre na 'Ilha' do Pinhém. Estudos Avançados Rev. São Paulo, v. 15, n. 42, p. 413448, maio/agosto de 2001.

ROSA, João Guimarães. Ficção completa. Rio de Janeiro: Nova Aguilar, 1994. 2 v. 991 e 1191 p.

ROSA, João Guimarães. Grande sertão: veredas. $11^{a}$ ed. Rio de Janeiro: José Olympio, 1976. 462 p.

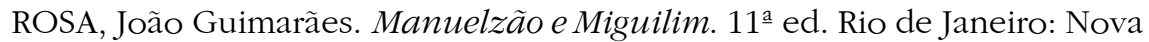
Fronteira, 2001. 265 p.

ROSA, João Guimarães. Correspondência com seu tradutor alemão Curt Meyer-Clason. Edição, organização e notas Maria Aparecida Faria Marcondes Bussolotti; tradução Erlon José Paschoal. Rio de Janeiro: Nova Fronteira: Academia Brasileira de Letras; Belo Horizonte: Ed da UFMG, 2003. 448 p.

ROSA, Vilma Guimarães. Relembramentos: João Guimarães Rosa, meu pai. Rio de Janeiro: Nova Fronteira, 1983. 457 p.

SANTOS, Júlia C. F. Nomes dos personagens em Guimarães Rosa. Rio de Janeiro: INL, 1971. 244 p.

SCHWARZ, Roberto. Grande sertão: a fala. In: . A sereia e o desconfiado: ensaios críticos. Rio de Janeiro: Civilização Brasileira, 1965. p. 23-27. 
SOARES, Claudia Campos. Movimento e ordem nos gerais rosianos: a família e a formação do herói em "Campo geral". São Paulo: USP, 2002. 187 p. (Tese de doutorado).

VIANNA, Oliveira. Populações meridionais do Brasil - populações rurais do centro-sul. 7. ed. Belo Horizonte: Itatiaia; Niterói: Editora da Universidade Federal Fluminense, 1987. 288 p. [Coleção Reconquista do Brasil]

WISNIK, José Miguel. Cajuína transcendental. In: BOSI, Alfredo. Leitura de poesia. São Paulo: Ática, 1996, p.191-219.

\section{Resumo}

"Campo geral" - primeira novela de Corpo de baile, de Guimarães Rosa - é narrada em terceira pessoa, mas seu leitor apreende a realidade ficcional da forma como ela é percebida por um menino que tem entre sete e oito anos de idade. O narrador está muito próximo de Miguilim, o que lhe permite a expressão das nuances mais delicadas da subjetividade do menino.

A realidade ficcional é apreendida, pois, da perspectiva de uma criança. Além disto, esta criança é extremamente sensível e não se identifica com os valores utilitaristas que vigoram em seu meio. Por isto é arredia e introspectiva, quase isolada; e costuma temer os adultos quase como o contágio de uma doença ruim. Por fim, Miguilim, a criança sob cuja visão nos é dado acompanhar os acontecimentos ficcionais, é míope, metáfora-síntese das limitações de sua perspectiva. Devido a tudo isto, só temos informações vagas e imprecisas acerca de graves acontecimentos que ocorrem na estória.

O ponto de vista de "Campo geral", entretanto, conjuga esta "visão imperfeita" (a de Miguilim) com a possibilidade de ver um pouco além dela. Ainda que o campo de visão do leitor seja limitado às possibilidades do menino míope, o autor cria outras condições de reconhecimento do ambiente e dos conflitos familiares que cercam Miguilim para além de sua capacidade de visão. De forma indireta, e aparentemente quase acidental, ele nos dá a ver o que o menino não pode de várias formas. São estas formas, e o jogo de elucidação e ocultamento que armam, que este estudo se propõe a investigar. 


\section{Abstract}

"Campo geral", the first novel of Corpo de Baile, narrates the story of a 7 year-old boy, Miguilim, in the third person. The reader, however, apprehends the ficcional reality as it was perceived by this boy. The narrator is very close to Miguilim and this proximity provides him the possibility to express the more slight details of the character's subjectiveness and makes the reader to capture the boy's subtle perception of his surrounded reality.

Miguilim is an extremely tender child who rejects the pragmatic values of the adult world. As a consequence, he is a solitary and introspective, almost lonely child, who evades from adult contact. In addition, Miguilim is also myopic, metaphor-synthesis of his own limited perception of the surrounded reality. Given this scenario, readers grasp only vague and imprecise information of the serious events that take place in the story. However, the point of view of "Campo geral" associates that "imperfect vision" (from Miguilim) with the possibility of seeing a little bit far from it. Even though the reader is limited to interpret the story from a myopic kid's perception, the author creates situations where familiar conflicts and events surrounding Miguilim might be apprehend beyond his own perception. Indirectly and almost accidentally, the author reveals to the reader what the kid cannot see himself. This study intends to investigate this game of elucidation and concealment created by Guimarães Rosa in the point of view of "Campo geral". 